\title{
Numerical investigation of the effect on ultimate loading capacity of different longitudinal reinforcement ratios of a RC portal frame
}

\author{
M. Karaton*, H.A. Awla \\ Furat University, Civil Engineering Department, Elazı̆g, Turkey
}

\begin{abstract}
In this study, the nonlinear static Pushover analyses of a reinforced concrete portal frame are obtained by using Fiber element method based on displacement. For calculating of cyclic behavior of concrete, the Mander-Priestley-Park model is used. Cyclic behavior of the reinforcement is obtained by using MengottoPinto steel model. Different longitudinal reinforcement ratios are selected for investigating effect on the nonlinear behavior of a portal frame under horizontal forces. Concrete mean strength is $20 \mathrm{MPa}$ and confinement factor is 1.2. The yield strength of reinforcement model is $420 \mathrm{MPa}$. Obtained results are evaluated with regard to the top displacement-base shear force and top rotation-base moment. The lateral load capacities and the overturning moment capacities obtained from $2^{\text {nd }}, 3^{\text {rd }}, 4^{\text {th }}$ and $5^{\text {th }}$ cases were calculated more between $81-200 \%$ and $101-286 \%$ than $1^{\text {st }}$ case, respectively. As a results, it is determined that the lateral load capacity and the overturning moment capacity increase depending on increasing of longitudinal reinforcement ratio in columns.
\end{abstract}

\section{Keywords}

Reinforced concrete; Portal frame; Pushover analysis; Fiber element; Longitudinal reinforcement ratio

Received: 09 September 2018; Accepted: 01 October 2018

ISSN: 2630-5763 (online) C 2018 Golden Light Publishing® All rights reserved.

\section{Introduction}

In the last decades more accurate and sophisticated methods developed after improvement in computational abilities and development of technology. One of these methods is dynamic analysis (time history analysis), known by its ability to predict more realistic approximation of structural elements response [1]. Forces and displacement values obtained from time history analysis in the structure vary depending on time. A method called as "Response Spectrum Method" is developed for obtaining peak force and displacement values in a structure [2]. In this method, a response curve is drawn by using maximum response values obtained for different natural vibration periods of a structure. A lot of time-history analysis of a building are used for this procedure. In time-history analysis, $2^{\text {nd }}$-order differential equation of the building is solved by using one of step by step integration methods $[1,2]$. A lot of researcher, investigated nonlinear behavior of the building under static, cyclic loading and acceleration loading and exerted so more effort for modelling of this nonlinear behavior [3-5]. Therefore, modelling of nonlinear behavior has been an important research area from past to present [6,7]. Nonlinear behavior is used for timehistory analysis of the building, more solution time and memory are requiring than linear elastic solution. Thus, nonlinear static analysis called as

\footnotetext{
Corresponding author

E-mail: mkaraton@firat.edu.tr
} 
"Push-over Analysis" is preferred for determining to nonlinear dynamic response of the building. This solution procedure is based on principal to loading until collapse of the building under monotonically increasing lateral loading. The loading is applied at upper point of the building as a force or a displacement. As a result, graph of base shear force-top displacement of the structure is obtained. Performance point of the building is determined when this graph is intersected with demand curve of the earthquake [2].

In this study, the nonlinear static Pushover Analysis of a reinforced concrete portal frame is obtained by using distributed plasticity based on displacement method. Solution was achieved using SeismoStruct [6], five cases were investigated with regard to the top displacement-base shear force and top rotation-base moment.

\section{Theory of fiber element method}

There are two types of nonlinear modeling, distributed plasticity method and lumped plasticity method. In first type element modelling, two zero length nonlinear rotation spring connected by elastic beam/column elements uses. The spring computes nonlinear behavior of structure during loading. The second one is discretized sections into fibers and the length into integration sections and it is called Fiber Element Analysis (Fig. 1). The method is distributed plasticity and two main principle formulations are used, displacement based (DB) stiffness approach and force based (FB) flexibility approach [6].

\subsection{Modeling the cyclic behavior of concrete}

Behavior of a concrete cross-section subjected to cyclic loading can be obtained by the realistic hysteretic stress-strain relations of it. The first study to characterizing cyclic behavior of concrete was done on 48 concrete cylinders tested by Sinha et al. [7]. An analytical expression in their study was developed by using the yielded data. They assumed that developed the stress-strain relationship is uniqueness to product the behavior of concrete, uniqueness means that unloading and reloading of stress-strain independent to its previous cycle. This hypothesis was refuted later by evidence. Another formula for the stress-strain relationship of concrete was presented by Karsan and Jirsa [8] and it base on the residual amount of plastic strain obtained in the previous loading cycle (Fig. 2). The results are obtained through testing 48 short columns under cyclically axial compression load [7]. Yankelevsky and Reinhardt [9] proposed a simple uniaxial stress-strain model based on geometrical properties of the loading history curves in the uniaxial stressstrain plane. This research was defined with complete unloading-reloading cycle by a set of pieced linear. An advance model for ordinary and high strength concrete was developed for both confined and unconfined concrete in cyclic compression and tension by Chang and Mander [10]. Unloading and reloading curves defined by behavior of concrete under cyclic loading. For understanding the concrete compression properties statistical analysis was conducted by Sinha et al. [7], Karsan and Jirsa [8], Spooner and Dougill [11], Okamoto et al. [12] and Tanigawa and Uchida [13].

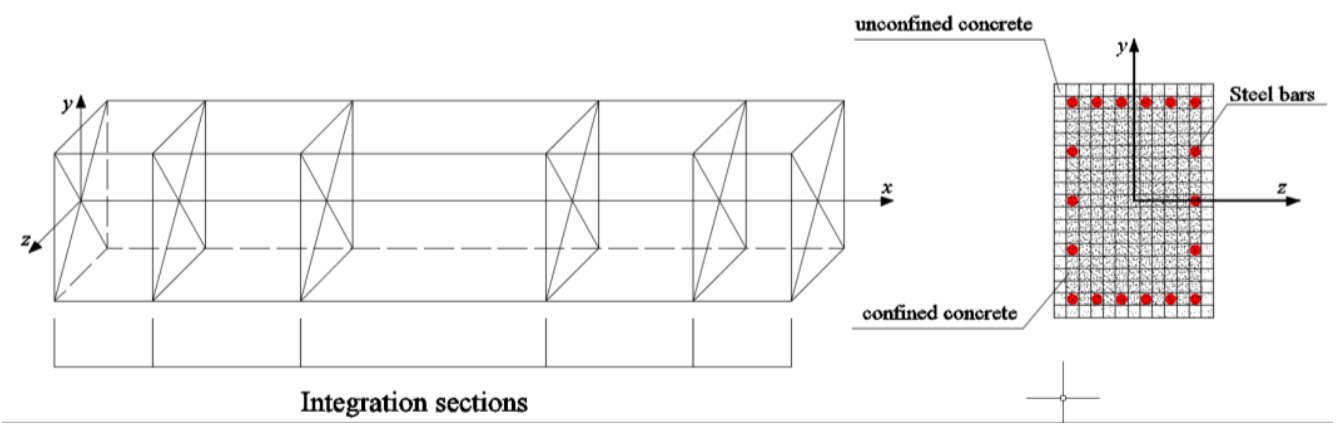

Fig. 1. Fiber model of a reinforced concrete beam/column member [6] 
These authors proposed some expressions for compression with the tension cyclic response. It was seen that a good overlap with experimental results obtained to demonstrate the behavior of concrete under cyclic compression loading for equation derived by Bahn and Hsu [14]. These relations are linear for reloading and curve for unloading. Mansour and Hsu [15] developed the Softened Membrane Model [16] for reversal cyclic shear stress, the development takes account "Softening" of the concrete compression strength subjected to cyclic uniaxial loading. The unloading and reloading curves were derived for this behavior (Fig. 3).

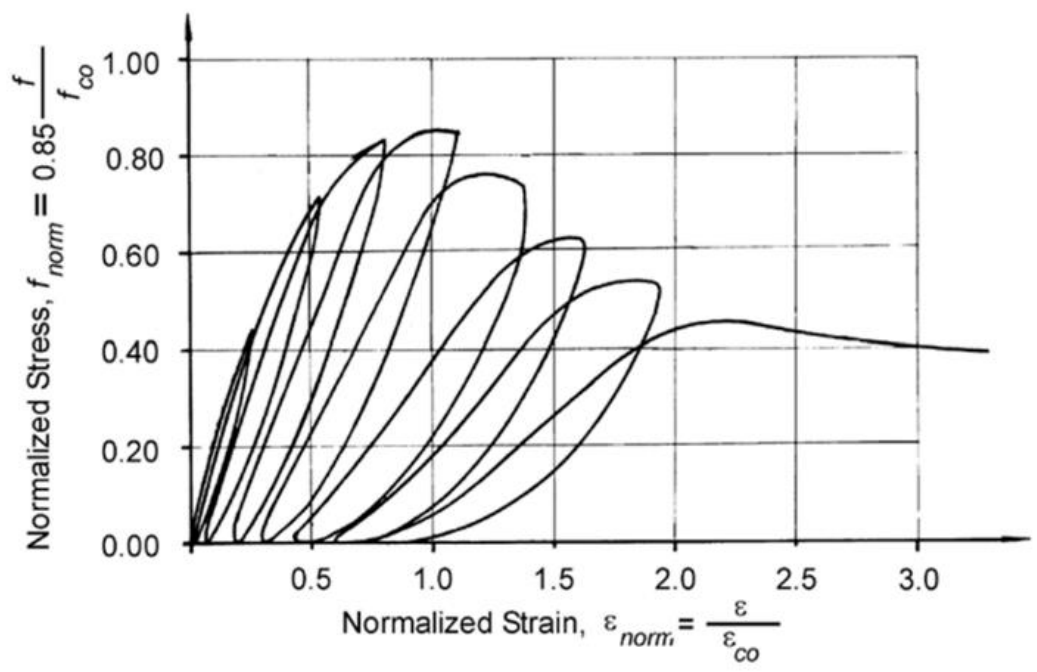

Fig. 2. Typical result of cyclic compression test [5]

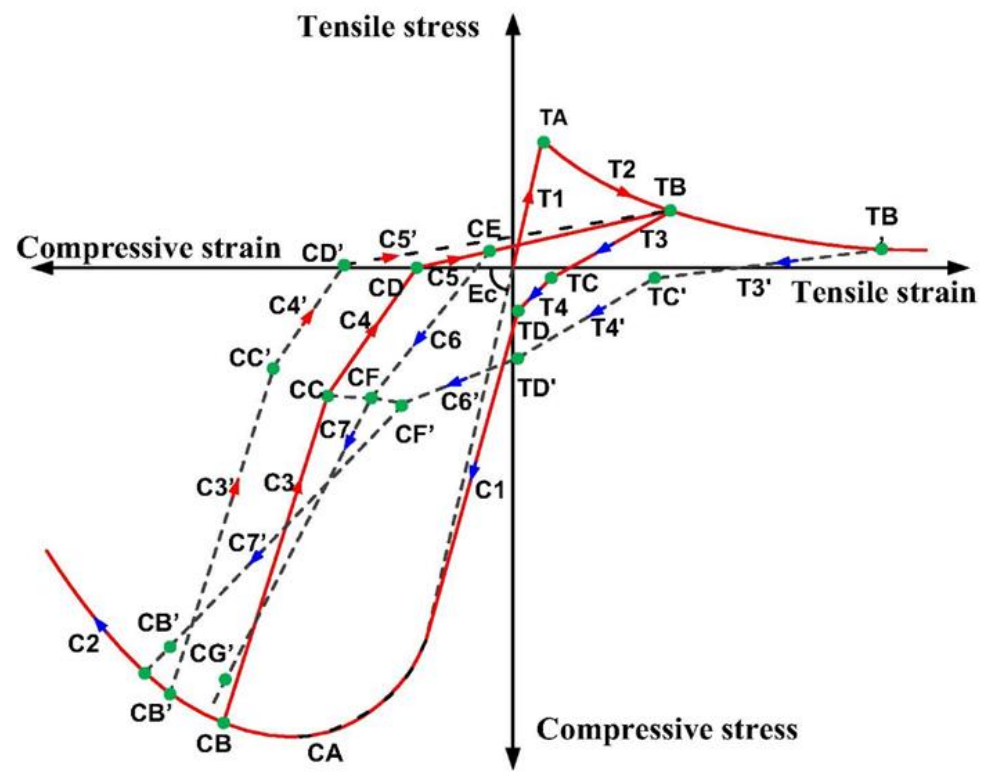

Fig. 3. Analytical model for cyclic stress-strain curve of concrete $[5,15]$ 
Concrete does not experience only full unloadingreloading cycles during earthquake, but partial unloading-reloading cycles may occurred in compression and tension. Mander, Priestley and Park [17] developed a stress-strain model for a transverse reinforced confined concrete subjected to uniaxial reversed compression loading with tension. The model was based on the equations of developed by Popovics [18] for concrete subject to monotonic compression loading. Stress-strain curves were generated in modelling of unloading and reloading cases for confined and unconfined concrete (Fig. 4). Material property data was only required for unconfined concrete. However, material and section properties are used for confined concrete curve, defining based on compression strength of concrete and ratio of the confinement steel stirrups in the cross section. Martinez-Rueda and Elnashai [19] modified this model to include stiffness and strength degradation for cyclic loading. Sakai and Kawashima [20], based on a set of column specimen tests proposed a model for concrete subjected to unloading and reloading cycles.

\subsection{Modeling the cyclic behavior of steel reinforcement}

Stress in the material can exceed to yield strength when steel subjected to cyclic loading. In this case, linearity of elasticity modulus of the steel losses prior to threshold of its yield strength. As seen in Fig. 5, this behavior is called as Bauschinger effect [21].

Mengotto and Pinto [21] proposed a hysteretic curve for uniaxial nonlinear behavior of steel material. This model is extended by Filippou et al. [22] to include isotropic hardening effects. As shown in the Fig. 6, the relation is in the form of curved transitions between the first straight line asymptote with slope E0 (Modulus of elasticity) and second straight line asymptote with slope $\mathrm{E}_{1}=b \mathrm{E}_{0}$ (Yield modulus) which $b$ is the strain hardening ratio, the curvature of the transition curve between the two asymptotes is defined by a cyclic curvature parameter $R$, which permits the Bauschinger behavior, the curvature totally governed with the strain-stress increasing or decreasing, the strainstress values $\left(\varepsilon_{r}, \sigma_{r}\right)$ and $\left(\varepsilon_{0}, \sigma_{0}\right)$ updated after each strain reversal. Also isotropic hardening included in compression and tension through optional values $a_{1}$ and $a_{2}$ for isotropic strain hardening in compression, and $a_{3}$ and $a_{4}$ for isotropic strain hardening in tension. When isotropic hardening excluded default values $a_{1}=a_{2}=0$, and $a_{3}=a_{4}=1$ are used. To including in compression value of parameters $a_{1}=0.01$ and $a_{2}=7.0$, also in tension values $a_{3}=0.01$ and $a_{4}=7.0$ recommended [22].

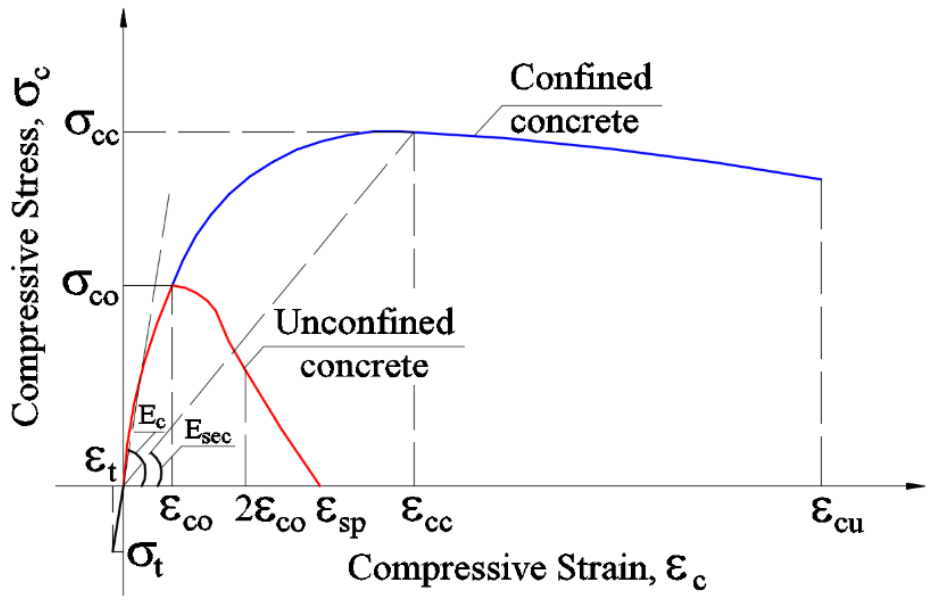

Fig. 4. Concrete model of Mander et al. [17] 


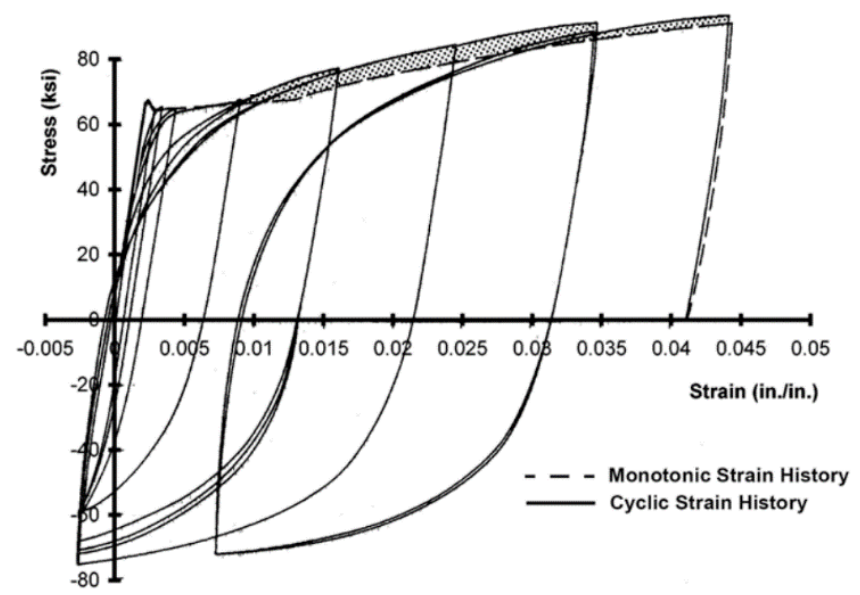

Fig. 5. Response of reinforcing steel subjected to reversed cyclic loading [21]

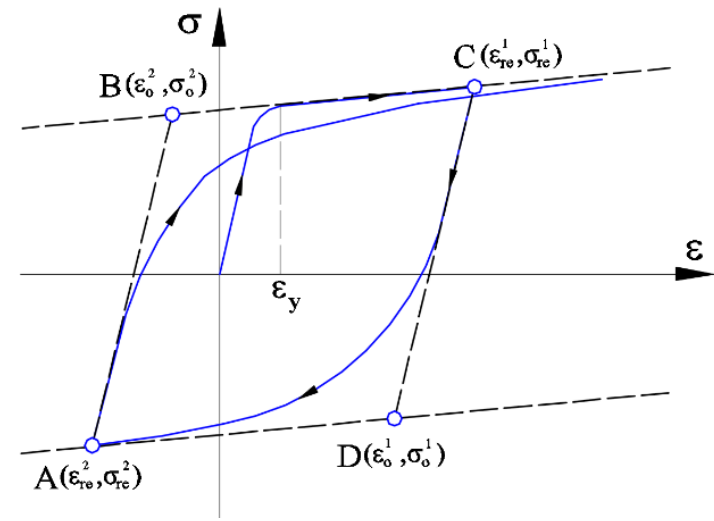

Fig. 6. Mengotto and Pinto [21] model for steel

\section{Numerical application}

In this study, static pushover analyses of a reinforced concrete portal frame are obtained for different longitudinal reinforcement ratios. SeismoStruct software [6] is used for the numerical solutions. Nonlinear behavior of reinforced concrete element is selected displacement based Fiber element method. As shown in Fig. 7, finite element model of the frame is given. Height and length of the frame with one story-one bay are $3 \mathrm{~m}$. Beam is rectangular cross-section as $25 \times 50 \mathrm{~cm}$ and columns are square cross-section as $40 \times 40 \mathrm{~cm}$.

Five different longitudinal reinforcement ratios in the columns are selected for investigating effect on the static push over analysis of its. The longitudinal reinforcement is constant for the beams $(3 \varnothing 12 \mathrm{~mm}$ continuous bar for the bottom and $2 \varnothing 12 \mathrm{~mm}$ continuous bar for the top), also transverse reinforcement is same and constant for the beam and columns (Ø8 mm @ $20 \mathrm{~cm} \mathrm{c} / \mathrm{c}$ ) for all five cases. The longitudinal reinforcement ratio used within columns are $\rho_{1}=0.00439, \rho_{2}=0.00867$, $\rho_{3}=0.01135, \rho_{4}=0.0144$ and $\rho_{5}=0.0178$ called which called as case1, case2, case 3 , case4 and case5, respectively (Table 1).

The model of Mander et al. [17] is used for calculating of cyclic behavior of concrete. In this model, compressive strength, mean tensile strength and elasticity modulus of concrete are $20 \mathrm{MPa}$, 1.565 MPa and 28534.44 MPa, respectively. 


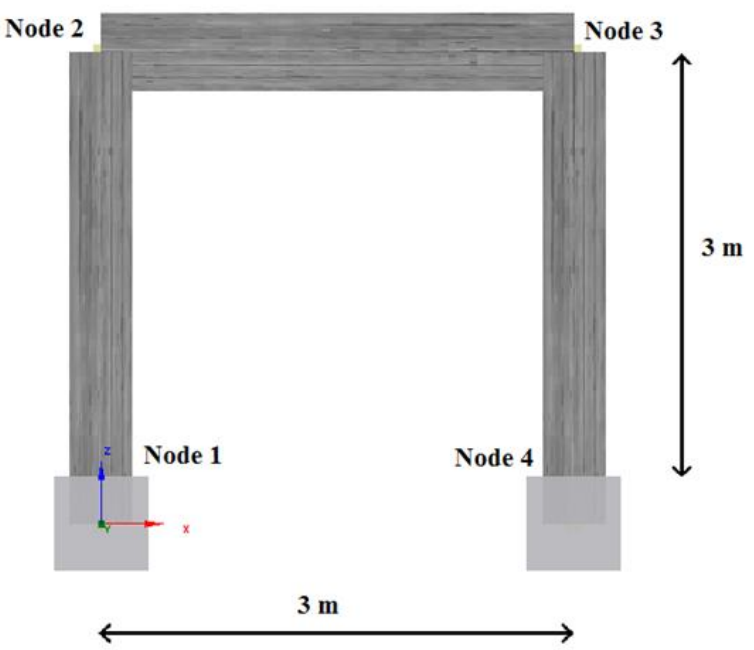

Frame $3 \times 2 m$ c/c

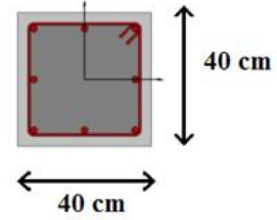

Column cross-section $40 \times 40 \mathrm{~cm}$

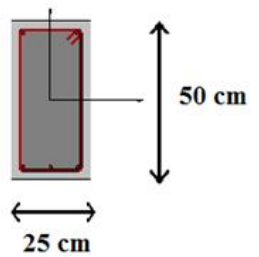

Beam cross-section $25 \times 50 \mathrm{~cm}$

Fig. 7. Finite element model of portal frame and cross section properties of columns/beam

Table 1. Geometric properties of beam and columns for using in the solutions

\begin{tabular}{ccc}
\hline & $\begin{array}{c}\text { Longitudinal } \\
\text { reinforcement } \\
\text { detailing in } \\
\text { columns }\end{array}$ & $\begin{array}{c}\text { Longitudinal } \\
\text { reinforcement ratio } \\
(\rho)\end{array}$ \\
\hline Case 1 & $8 \phi 10$ & 0.00439 \\
Case 2 & $8 \phi 14$ & 0.00867 \\
Case 3 & $8 \phi 16$ & 0.01135 \\
Case 4 & $8 \phi 18$ & 0.01440 \\
Case 5 & $8 \phi 20$ & 0.01780 \\
\hline
\end{tabular}

Strain at peak compressive strength is 0.002 and specific weight is $24 \mathrm{KN} / \mathrm{m}^{3}$ and confinement factor is 1.2 , mean strength value is $20 \mathrm{MPa}$, characteristics or Nominal value is 813.3 MPa. The reinforcement model is Mengotto-Pinto steel model $[21,22]$. In this model, the yield strength, modulus of elasticity, specific weight, strain hardening parameter is selected as $420 \mathrm{MPa}, 200000 \mathrm{MPa}, 78$ $\mathrm{kN} / \mathrm{m}^{3}$, and 0.005 , respectively. In the hysteresis behavior of steel, transition curve shape calibrating coefficients that $a_{1}$ and $a_{2}$ were selected as 18.5 and 0.15 . Isotropic hardening calibrating coefficient, $a_{3}$ is 0.0 . Fracture/buckling strain is 0.1 , mean strength value is $500 \mathrm{MPa}$, characteristics or Nominal value is also $434.783 \mathrm{MPa}$.

In this study, the nonlinear static Pushover Analysis of a reinforced concrete portal frame is obtained by using distributed plasticity based on displacement method. Solution was achieved using SeismoStruct [6], five cases were investigated with regard to the top displacement-base shear force and top rotation-base moment. Top displacement-base shear force curves for all cases were given in Fig. 8. Maximum displacement value of top point of the frame was calculated as $400 \mathrm{~mm}$ for all cases. Maximum base-shear force in $1^{\text {st }}, 2^{\text {nd }}, 3^{\text {rd }}, 4^{\text {th }}$ and $5^{\text {th }}$ cases was obtained as $114.26 \mathrm{kN}, 206.79 \mathrm{kN}$, $255.03 \mathrm{kN}, 302.44 \mathrm{kN}$ and 343.23, respectively. Lateral load capacities obtained from $2^{\text {nd }}, 3^{\text {rd }}, 4^{\text {th }}$ and $5^{\text {th }}$ cases were calculated more $81,123,165$ and $200 \%$ than $1^{\text {st }}$ case, respectively. It was determined that the lateral load capacity increase by increasing reinforcement ratio in columns.

Top rotation-base bending moment curves for all cases were given in Fig. 9. Maximum displacement value of top point of the frame was calculated as $400 \mathrm{~mm}$ for all cases. Maximum base bending moment in $1^{\text {st }}, 2^{\text {nd }}, 3^{\text {rd }}, 4^{\text {th }}$ and $5^{\text {th }}$ cases was obtained as $186.89,375.93,498.53,613.41$ and 


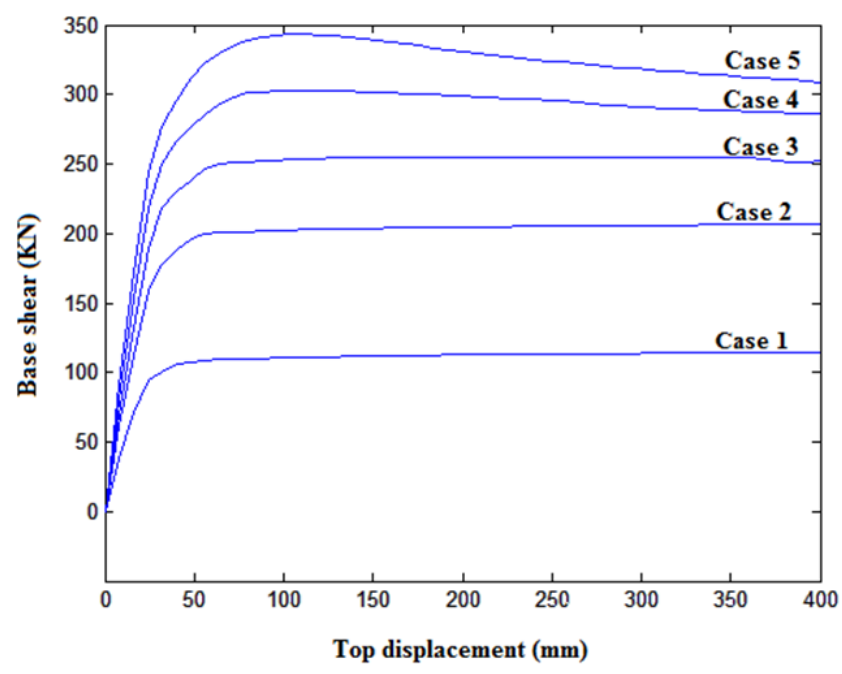

Fig. 8. Top displacement-base shear force curves for all cases

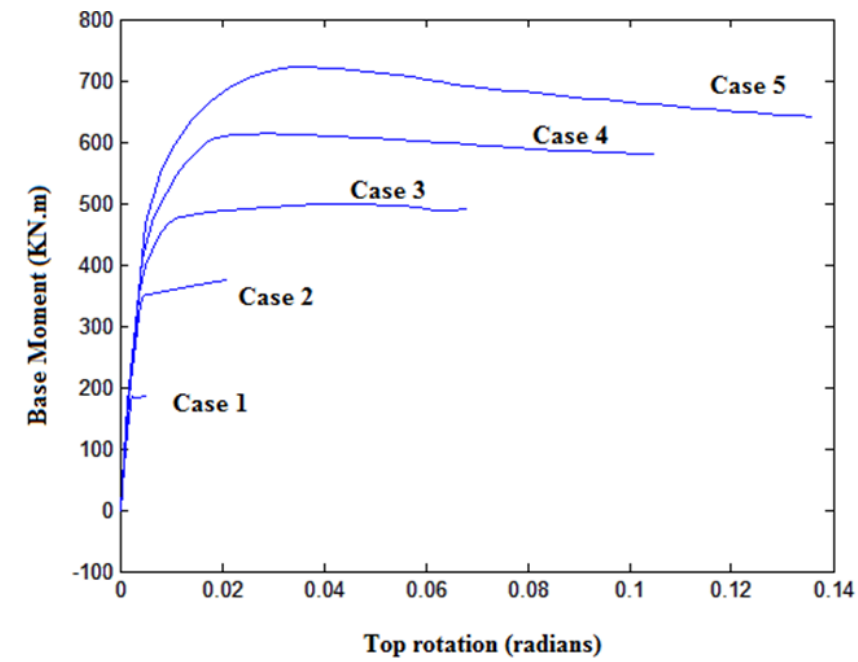

Fig. 9. Top rotation-base bending moment curves for all cases

721.17 kN.m, respectively. Moment capacity obtained from 2nd, 3rd, 4th and 5th cases were calculated more 101, 167, 228 and $286 \%$ than 1 st case, respectively. It was determined that the overturning moment capacity of the frame increase by increasing reinforcement ratio in columns.

\section{Results}

In this study, the nonlinear static Pushover Analysis of a reinforced concrete portal frame is obtained by using distributed plasticity based on displacement method. For calculating of cyclic behavior of concrete, the model of Mander et al. is used. Mengotto-Pinto steel model is selected for modelling to cyclic behavior of the reinforcement. Solutions were obtained by using SeismoStruct program. Five cases investigated for five different longitudinal reinforcement ratios in the columns. Results are evaluated with regard to the top displacement-base shear force and top rotationbase moment. The lateral load capacities and the overturning moment capacities obtained from $2^{\text {nd }}$, 
$3^{\text {rd }}, 4^{\text {th }}$ and $5^{\text {th }}$ cases were calculated more between $81-200 \%$ and $101-286 \%$ than $1^{\text {st }}$ case, respectively.

\section{References}

[1] Bathe KJ. Finite Element Procedures in Engineering Analysis. Prentice hall, Englewood Cliffs, New Jersey, 1982.

[2] Chopra AK. Dynamics of Structures: Theory and Applications to Earthquake Engineering, 5th Edition, Prentice Hall, New Jersey, 2012.

[3] Sharma A, Reddy G, Vaze K (2012) Shake table tests on a non-seismically detailed RC frame structure. Structural Engineering and Mechanic. 41:1-24.

[4] Hsiao FP, Oktavianus $\mathrm{Y}, \mathrm{Ou} \mathrm{YC}$, Luu CH, Hwang SJ (2015) A pushover seismic analysis and retrofitting method applied to low-rise RC school buildings. Advanced Structural Engineering.18: 311-324.

[5] Mo YL, Luu CH, Nie X, Tseng CC, Hwang SJ (2017) Seismic performance of a two-story unsymmetrical reinforced concrete building under reversed cyclic bi-directional loading. Engineering Structures. 145(5): 333-347.

[6] Earthquake Engineering Software Solution [2013], SeismoStruc Ver 6, www.seismosoft.com.

[7] Sinha BP, Gerstle KH, Tulin LG (1964) Stressstrain relations for concrete under cyclic loading. ACI Structural Journal. 61(2): 195-211.

[8] Karsan ID, Jirsa JO (1969) Behavior of concrete under compressive loadings. Journal of the Structural Division, ASCE. 95(ST12): 25432563.

[9] Yankelevsky DZ, Reinhardt HW (1987) Model for cyclic compressive behavior of concrete. Journal of Structural Engineering ASCE. 113(2): 228-240.

[10] Chang GA, Mander JB. Seismic energy based fatigue damage analysis of bridge columns: Part I - Evaluation of seismic capacity, Technical Report NCEER-94-0006. State University of New York at Buffalo, 1994.

[11] Spooner DC, Dougill JW (1975) A quantitative assessment of damage sustained in concrete during compressive loading. Magazine of Concrete Research. 27(92): 151-160.

[12] Okamoto S, Shiomi S, Yamabe K (1976) Earthquake resistance of prestressed concrete structures. Proceedings Annual Convention AIJ: 1251-1252.

[13] Tanigawa Y, Uchida Y (1979) Hysteretic characteristics of concrete in the domain of high compressive strain. Proceedings Annual Convention AIJ: 449-450.

[14] Bahn BY, Hsu CT (1998) Stress-strain behavior of concrete under cyclic loading. ACI Materials Journal, 95(2): 178-193.

[15] Mansour M, Hsu TTC (2005) Behavior of reinforced concrete elements under cyclic shear. II: theoretical model. Journal of Structural Engineering ASCE. 131(1): 54-65.

[16] Hsu TTC, Zhu RRH (2002) Softened membrane model for reinforced concrete elements in shear. ACI Structural Journal. 99(4): 460-469.

[17] Mander, JB, Priestley MJN, Park R (1984) Theoretical stress-strain model for confined concrete. Journal of Structural Engineering. ASCE. 114(3). 1804-1826.

[18] Popovics S (1973) A review of stress-strain relationships for concrete. Journal of the ACI. 67(3): 243-248.

[19] Martinez-Rueda E, Elnashai AS (1997) Confined concrete model under cyclic load. Materials and Structures. 30: 139-47.

[20] Sakai J, Kawashima K (2006) Unloading and reloading stress-strain model for confined concrete. Journal Structural Engineering. ASCE. 132(1): 112-22.

[21] Menegotto M, Pinto PE Method of analysis for cyclically loaded R.C. plane frames including changes in geometry and non-elastic behaviour of elements under combined normal force and bending. Symposium on the Resistance and Ultimate Deformability of Structures Acted on by Well Defined Repeated Loads. International Association for Bridge and Structural Engineering, 15-22, 1973, Zurich, Switzerland.

[22] Filippou FC, Popov EP, Bertero VV. Effects of bond deterioration on hysteretic behavior of reinforced concrete joints. Report No. UCB/EERC 83-19. EERC, University of California, Berkeley, 1983. 